\title{
Alleviation of Refugee Crisis in Lebanon through Humanitarian Aid Projects of Slovak Development Organizations in the Era of Covid-19 Pandemic
}

\section{B. Markovic Baluchova (Bozena Markovic Baluchova)}

${ }^{1}$ Department of Development and Environmental Studies, Faculty of Science,

Original Article Palacky University in Olomouc, U1. 17. listopadu 12, 77146 Olomouc,

Czech Republic.

${ }^{2}$ Ambrela - Platform for Development Organizations, Mileticova 7, 82108 Bratislava, Slovakia.

\section{E-mail address:}

boba.baluchova@gmail.com

\section{Reviewers:}

Andrea A Shahum

Chapel Hill NC, USA

Claus Muss

IGAP Zurich $\mathrm{CH}$

\section{Reprint address:}

Bozena Markovic Baluchova

Department of Development and Environmental Studies, Faculty of Science

Palacky University in Olomouc,

Ul. 17. listopadu 12

77146 Olomouc

Czech Republic

Source: Clinical Social Work and Health Intervention

Volume: 12

Issue: 1

Pages: $63-68$

Cited references: 14

\section{Publisher:}

International Society of Applied Preventive Medicine i-gap

\section{Keywords:}

Humanitarian Aid. SlovakAid. ODA. Lebanon. Refugees. Migration. Covid-19 Pandemic. Ambrela

- Platform for Development Organizations.

CSWHI 2021; 12(1): 63 - 68; DOI: 10.22359/cswhi_12_1_13 CC Clinical Social Work and Health Intervention

\section{Abstract:}

Lebanon hosts the highest number of refugees in the world in relation to its population (every seventh inhabitant is a refugee). In light of the events of Spring 2020, new concerns emerge: how will the living conditions of the domestic and refugee communities in Lebanon, already burdened by the economic crisis, be exacerbated by the Covid-19 pandemic? In this paper, the Slovak intervention by members of Ambrela - Plat- 
form for Development Organizations is presented. It focuses on preventing and addressing the causes of migration by improving the living conditions of the population and its prospects for finding employment in home communities. Study also shows the impact on alleviation of the refugee crisis in Lebanon under the SlovakAid brand by the recent humanitarian crisis related to the Covid-19.

\section{Introduction}

Currently, the small Middle Eastern country of Lebanon with its population of 6.8 million (World Population Review, 2020) is experiencing a political, financial and refugee crisis all at the same time. It is home to around one million refugees displaced by the war in nearby Syria, lasting since 2011. If we add up hundreds of thousands of Palestinian refugees displaced from society, who have been traveling to the country since 1948 until this day, the number may increase significantly (Markovic Baluchova, 2020). This small country on the Mediterranean coast, where Shiites, Sunnis and Christians share power, still has the highest number of refugees per capita in the world (UNHCR, 2020). Lebanon, tried by the 19751990 civil war and the wars with Israel (1982 \& 2006), has not collapsed nor disintegrated. Still, the Spring hunger strikes impacted by the Covid19 pandemic may further deepen the internal disintegration and collapse of the state.

The problems associated with the refugee crisis are not manageable in the long run. The growing number of refugees from Syria is a heavy burden, especially for Lebanon's infrastructure and labor market. This is an issue especially in the Bekaa Valley, where more than 300,000 refugees live. Due to the legal vacuum, many fleeing people end up in the infamous Palestinian refugee camps of Sabra and Shatila in Beirut. Families in need live there in inhospitable conditions. There is dirty water close by the tents, garbage heaps, no sewerage, the roads are dusty, and electricity is expensive (Toda, 2016).

The European Union and its member states (including Slovakia) work to assist the Lebanese government in addressing the above-mentioned crises. One of the EU's strategies to deal with the refugee crisis and the growing number of people fleeing from the Middle East and
North Africa into Europe is to help the countries most affected by the crisis and closest to its epicenter. Lebanon may serve as an instance of what such aid looks like in practice. Since the outbreak of the so-called migration and refugee crisis, the Slovak Republic has been intensively involved in humanitarian activities in Lebanon. It has been focusing on preventing and addressing the causes of migration by improving the living conditions of the population and its prospects for finding employment in home communities. Special attention has been paid to improving the living conditions of refugees with an aim to assist them in their temporary stay in host countries, or their return to their countries of origin. (SlovakAid, 2019) Since 2016, the Slovak Republic has been implementing humanitarian projects there through official development assistance (ODA). The Slovak Agency for International Development Cooperation (SAIDC) has supported 9 humanitarian projects in Lebanon under the brand of SlovakAid so far.

\section{Methodology and Research Participants}

The aim of the paper is to identify activities of Slovak organizations alleviating the refugee crisis in Lebanon and to analyse an impact of global pandemic Covid-19 on these activities as part of ongoing Humanitarian Aid projects. Qualitative research methods (content analysis of project documents, as well as nonprofits' websites and following structured interviews with project managers from particular aid nonprofits) have been chosen for validation.

First research participant was ADRA Slovakia - a Slovak humanitarian and development organization which operates in low-income countries and at home. It is part of the international organization ADRA (Adventist Development and Relief Agency), and in 2018 it 
celebrated 25 years of its existence. From August 2019 to August 2020, in cooperation with the partner ADRA Lebanon, the organization implemented a project in the field of WASH (i.e. water, sanitation and hygiene) entitled, WASH Intervention in the Baalbek Area for Syrian refugees and the Lebanese (ADRA Slovakia, 2019).

The organization People in Need (PiN) also took an active part in the research and Ambrela's Case Study (Markovic Baluchova, 2020). It just finished its third project in Lebanon. The history of the organization dates back to 1999 when it was established in response to the situation in war-torn Kosovo. In 2016, PiN merged with Czech humanitarian and development organization People in Need, and today it operates as a non-profit organization as a part of the international People in Need network. From August 2019 to the end of August 2020, the organization was implementing a project entitled Education as a Pathway to Better Living Conditions for Vulnerable Children and Youth From Lebanese and Refugee Communities in Tripoli (People in Need, 2019) in the second largest city in Lebanon.

The medical humanitarian organization Magna was established in 2001 and started providing medical assistance to disaster victims around the world based on the direct experience of the founding couple with the AIDS epidemic in Cambodia. Today, through its hospitals, Magna provides health care, medicines and food to children and their families. It has its own medical and technical teams in the field, which provide the necessary help and treatment. Since October 2019, the organization has been implementing a project in Lebanon titled, Providing Reproductive Health Care, Including the Management of Cases of Sexual Violence, to Syrian Refugees and Internally Displaced Persons in the Baalbek-Hermel Areas (Magna, 2019), scheduled for completion in November 2020.

Another Ambrela member, Caritas Slovakia, assists more than 23,000 people in need each year through 10 diocesan/archdiocesan charities and its secretariat in Slovakia and abroad. In low-income countries, the organization implements its humanitarian and development projects - sometimes with the support of
SlovakAid, but more often thanks to the funding by private donors, church collections or with the support of the Conference of Bishops of Slovakia (CBS). The project titled, Supporting Education of Children of Palestinian Refugees is implemented thanks to the support of CBS for several years now. The activities take place in the Dbayeh Refugee Camp near Beirut, which was established in 1959 for the Palestinian community fleeing the armed conflict in Galilee. Currently, a fourth generation lives in the camp, making their living from casual work. However, during the civil war in Lebanon, the local school was destroyed and the children attended schools close by the camp. They were often harassed and attacked while commuting to school (Caritas Slovakia, 2019).

\section{Results}

Lebanon was already in a serious economic crisis before the onset of the COVID-19 pandemic, which has exacerbated it further. The Lebanese population is losing not only employment but also savings. A new wave of protests against anti-pandemic measures has risen. While the Autumn 2019 street protests against the ruling elites were peaceful, those of March 2020 seemed different and more dangerous (Daniel, 2020).

In March 2020, after the Covid-19 outbreak, Ambrela member organizations which implement humanitarian and development projects in the country had to reduce their activities and transform and adapt them significantly to the then current situation. The content analysis of documents and interviews with project managers from particular Slovak aid nonprofits were conducted from June to July 2020 - just a few weeks before the massive explosion of ammonium nitrate in Beirut port. Therefore, an aid intervention of Ambrela's members to this humanitarian crisis is not included into this research paper.

The main output of the ADRA's project was the construction of a water reservoir in Hay El Shaab Wal Zahrae within Baalbek. The aim was to ensure access to safe drinking water for the local community (21,000 Lebanese and 8,000 Syrian people). According to the latest information, the construction of the water reservoir was 
completed, but ADRA had to halt or suspend training on safe and hygienic use of water for locals in Baalbek. The activities were being transformed into training focused on hygiene and Covid-19 prevention. Before the COVID19 pandemic, only one such training was held in a camp for 25 families, which was attended mainly by women. Project manager AnnaMaria Benkova of ADRA Slovakia stated:

„The training participants expressed gratitude for the acquired knowledge and skills, but also for our interest in providing a helping hand and education which will translate into the care of their families. They also offered something like a needs assessment and ideas for future projects on how to improve living conditions with a bit of assistance.“

The PiN's project responded to the educational needs of children aged 4-10 to qualify for enrollment and maintain their regular school attendance. It also targeted young people, helping to increase the employability of the disadvantaged youth aged 16-26. Through field workers, in cooperation with the SEED partner, the project provided psychosocial support to children, young people, their families, as well as pedagogical staff. It also educated parents to support the educational environment for their offsprings: which then led to better school results; good habits and stronger motivation to learn. The project was positively received by local religious, ethnic and culturally diverse communities, which resulted in improved educational opportunities and livelihoods.

During the project implementation, the organization encountered obstacles which needed to be addressed and perceived as challenges. Project manager Viola Ternenyova from PiN stated that the biggest obstacle was the deepening socio-economic crisis in Lebanon:

„All essential products and services were highly expensive, families prioritized livelihoods over education, and the banking system ceased to function. The Lebanese currency was unsustainable and foreign currencies were unavailable. In practice, this meant difficulties in financing projects as well as in performing simple tasks. Nervousness and tension in society were growing, and the level of violence was rising.
The field work was extremely demanding, but at the same time, very instructive."

The organization People in Need provided education and psychological support through WhatsApp during the lockdown due to Covid19 pandemic. Moreover, it provided cell phone top-up credit for families who could not afford the Internet. It also started providing multifunctional meal tickets for families who could no longer afford to buy even basic food and hygiene products. Importantly, the organization also coordinated its activities with the activities of other organizations (People in Need, 2020).

The Magna's project provides needy and socially excluded people with access to health care, and strengthens the capacities of health structures and local staff to access and treat cases of sexual violence. Strengthening the professional capacities and raising awareness of promoting the rights of women and other groups of active civil society is equally important. The Chaat, Youmine and Baalbek refugee settlements in the Baalbek-Hermel area still do not provide quality reproductive health services, either mental health and psychosocial support for victims of sexual violence. In the Spring 2020 Magna adapted its activities to the current situation related to Covid-19 pandemic. The health and psychosocial support to refugee women address the current phase of the crisis, while there is an assumption that sexual violence may increase during the Covid-19 pandemic.

The project of Caritas Slovakia covers the costs associated with private transport for the children from economically weakest families in order to provide them with an opportunity to gain an education. In addition to transport, the project also provides them with school supplies, material equipment, and tutoring (Caritas Slovakia, 2019). Alena Horvathova from Caritas Slovakia explains:

„Thanks to the provision of school supplies, school fees, footwear, clothing, tutoring and transport, children from the poorest families of the Palestinian refugee community are able to attend school activities. Hence, they have hope for a better future than their parents, thus preventing the emergence of the so-called lost generation." Caritas also adapted their activities to the 
current situation related to the COVID-19 pandemic.

\section{Conclusion}

Economists believe that $50 \%$ of the Lebanese population already lives in poverty without a state social support network (Daniel 2020). Up to $95 \%$ of Syrian and Palestinian refugees are dependent on financial assistance. The country is in real danger of famine. Due to Covid-19 pandemic food prices have risen dramatically once again, with many people having lost their employment due to restrictions on movement and workplace closures. (Chehayeb, \& Sewell, 2020) Sufficient social isolation and maintaining a safe distance is not possible in the overcrowded refugee communities. The situation is the worst for those who live in tent settlements and therefore do not even have access to running water. The massive explosion of ammonium nitrate in Beirut port from August 2020 subsequently deepened the humanitarian crisis.

New project was supposed to start in Summer 2020 under the name Basic health care and nutrition program for refugees from Dbayeh camp in Beirut, implemented by St. Elizabeth University of Health and Social Work and supported by SlovakAid. The project aims to improve the health of refugees, especially from Syria. It may also be challenged by the current situation related to Covid-19 pandemic, as well as the aftermath of Beirut's deadly explosion.

Interviews by Slovak journalists (Toda, 2016), development field workers and development volunteers (Markovic Baluchova, 2020; People in Need, 2020) with refugees in Lebanon show that, most of all, they now need employment to provide livelihoods for their families. If possible, many of them would like to return home to Syria in the future. However, until it is safe and doable, Lebanon will need much help. All of the above-mentioned SlovakAid projects are contributing to the solution despite the current Covid-19 pandemic barriers and challenges.

\section{References}

1. ADRA SLOVAKIA (2019) A Source of Drinking Water for a Village in Lebanon [In Slovak language]. Available online: https://www.adra.sk/libanonrezervoar/.
2. CARITAS SLOVAKIA (2019) Projects in Lebanon [In Slovak language]. Available online: https://charita.sk/pomoc-utecencom/ nase-projekty/projekty-v-libanone/.

3. CHEHAYEB K, SEWELL A (2020) How COVID-19 Is Limiting Healthcare Access for Rugees in Lebanon. Available online: https://www.thenewhumanitarian.org/feature/2020/04/21/Lebanon-coronavirusrefugee-healthcare.

4. DANIEL J (2020) When Banks Burn. The Lebanese Revolution Between the Coronavirus and Economic Collapse [In Czech language]. Available online: https:// a2larm.cz/2020/05/kdyz-hori-banky-

libanonska-revoluce-mezi-koronavirem-aekonomickym-kolapsem/.

5. MAGNA (2019) Where We Help Lebanon. [In Slovak language]. Available online: https://www.magna.org/sk/kdepomahame/libanon/.

6. MARKOVIC BALUCHOVA B (2020) Examples of Humanitarian Aid Projects of Slovak Organizations in Lebanon (Case study). Available online: https://ambrela.org /wp- content/uploads/2020/07/Ambrela_ se_Study_Humanitarian_Aid_projects_Lib anon_2020.pdf.

7. MARKOVIC BALUCHOVA B (2020) [In Slovak language]. Available online: https:// mediaaboutdevelopment.wordpress.com/20 20/05/09/dobrovolnicka-anna-hrubonovatvarou-migracie/.

8. PEOPLE IN NEED (2019) Humanitarian Aid-Lebanon. [In Slovak language]. Available online: https://clovekvohrozeni.sk/humanitarna-pomoc/libanon/.

9. PEOPLE IN NEED (2020) Coronavirus and Our Projects Abroad [In Slovak language]. Available online: https://clovek vohrozeni.sk/koronavirus-a-nase-projektyv-zahranici/

10. PEOPLE IN NEED (2020) Estelle, a Humanitarian Worker in Lebanon: I Do Not Regret Taking the Last Flight [In Slovak language]. Available online: (https://clovek vohrozeni.sk/humanitarna-pracovnicka-vlibanone-rozhovor/.

11. SLOVAK AID (2019) Partner Countries and Regions - Middle East [In Slovak language]. Available online: https://www.slo- 
vakaid.sk/sk/ako-pomahame/partnerske-regiony-krajiny.

12. TODA M (2016) It Has the Highest Number of Refugees per Capita. We Looked into How the Small Country of Lebanon Can Survive [In Slovak language]. Available online: https://dennikn.sk/500403/ma-utecencov-cela-europa-sa-pozriet-moze-malylibanon-prezit/.

13. UNHCR (2020) Global Trends 2019. Available online: https://www.unhcr.org/globaltrends2019 .

14. WORLD POPULATION REVIEW (2020) Lebanon Population 2020. Available online: https://worldpopulationreview.com/ countries/lebanon-population/.

This paper (and conducted research) is a part of project entitled 'SDGs and Migration' implemented by Slovak Platform for development organizations - Ambrela within the framework of the DEAR programme. 